\title{
How Engaged Customers Can Help the Brand: An Empirical Case Study on a Higher Education Institution (University) in Egypt
}

\author{
Samia Adly Hanna El Sheikh ${ }^{1}$ \\ ${ }^{1}$ Faculty of Management Sciences, October University for Modern Sciences and Arts (MSA), Egypt \\ Correspondence: Samia Adly Hanna El Sheikh, Faculty of Management Sciences, October University for \\ Modern Sciences and Arts (MSA), Egypt. E-mail: selsheikh@msa.eun.eg
}

Received: September 11, 2018 Accepted: November 25, $2018 \quad$ Online Published: January 24, 2019

doi:10.5539/ijms.v11n1p85 URL: https://doi.org/10.5539/ijms.v11n1p85

\begin{abstract}
The purpose of this paper is to investigate through an empirical research the relationship between Customer Engagement Behavior (CEB) and some of its alleged outcomes that include Benevolence/Trust, affective commitment and future patronage in a service sector which is Higher Education. Thus, this research investigates customer engagement constructs of conscious attention and emotional participation that lead to various favorable behaviors by the customer, which in turn leads to favorable outcomes of benevolence, affective commitment and future patronage. The researcher starts by a survey of literature which handles various aspects of CEB which include: possible types of these behaviors, factors affecting CEB, outcomes of CEB and CEB as compared to other marketing concepts. Next, the researcher proposes a model where engaged students (CE) will undertake favorable behaviors (CEB) which in turn will lead to favorable outcomes of Benevolence/trust, future patronage/repurchase intention and affective commitment. The researcher tests the model using Partial Least Squares structural equation modeling (PLS-SEM) and empirical data from a survey (self-administered questionnaire) that was distributed among 5 faculties of one private university in Egypt based on a case study approach. The results show that we accept the hypotheses of the model of the model yet the researcher suggests application on other universities to further test the model. Moreover, the researcher invites further research of other favorable outcomes of CEB as loyalty to be considered. The researcher also suggests an investigation of unfavorable CEB as bad word of mouth (WoM) and harmful blogging or unfavorable reviews.
\end{abstract}

Keywords: Customer Engagement Behavior (CEB), customer engagement constructs (conscious attention \& emotional participation), benevolence/trust, affective commitment, future patronage/repurchase intention

\section{Introduction}

Customers are the most important resource of any organization. Customers can generate and add value to the organization or brand not only through the buying of the organization's products or services but in several different ways. Companies now realize the urgent and critical requirement to concentrate on building two ways relationships with their customers. Customers will create value to the organization once they get involved and engaged, thus they get into a closer and more realistic relationship with the organization. As such, the concept of customer engagement is increasingly becoming a major concern for both researchers and organizations (Kumar et al., 2010).

Customer Engagement has recently been one of the concepts that attract attention from many directions. First, the Marketing Science Institute (MSI) has set this concept as a priority for research during the period of 2010-2012 also, the Journal of Service Research has devoted a whole special issue on this concept in 2010 as well as several articles in another special issue with responses in 2011 (Jaakkola \& Alexander, 2014).

Moreover, there are a big number of conferences that were held as well as seminars, webinars that discussed customer and/or consumer engagement (Brodie et al., 2011). The concept was also of interest to many consulting firms as Nielsen Media Research, the American Association of Advertising Agencies and the Association of National Advertisers (Brodie et al., 2011).

Furthermore, there is a rather personal interest that extends from my work as a lecturer at university and how engaged students make all the difference in achievements in education. Education is one of several disciplines, in which engagement is a major concern especially more so with the "marketization" of higher education and with 
the expansion and increase in the various higher education institutions (universities, academies, affiliations and other), the concept of student engagement is becoming a key concern.

\section{Theoretical Background}

\subsection{CE in Marketing Literature}

As for the concept itself and its nature $\mathrm{CE}$ has become the center of attention by several marketing researchers and as such several papers have collected together the views of various researchers in a table of definitions ranging chronologically from 2010, to present, starting from Van Doorn et al. (2010) who stresses the behavioral aspect of engagement and defines customer engagement behavior (CEB) as the "behavioral manifestations" that have a firm or brand focus beyond purchase, moving on to Mollen and Wilson (2010) who define CE as the cognitive and affective relationship with a brand through its website that is online. In 2011, Hollebeek (2011) defines customer-brand engagement as a state of mind of the customer that includes a specific level of cognitive, emotional and behavioral activity towards a brand. Brodie et al. (2011) define CE as a psychological state that happens when there is an interaction between the customer and a brand in a service relationship where the customer shares in co-creating the service experience. While Vivek, Beatty and Morgan (2012) define CE as the intensity of participation of the customer in the relationship between the customer and the brand or activities of the organization, this connection or participation could be initiated by either the customer or the organization. Finally, in this study we can define customer engagement as a relationship between the customer and a brand or organization where the customer shows interest and attention towards a brand that is accompanied by an emotion or an attitude towards the brand; while CEB is the customer's behavioral manifestations that has a brand or firm focus, beyond purchase, resulting from motivational drivers (Marketing Science Institute, 2008).

\subsection{Common Aspects in Views of CE in Reviewed Literature}

The above mentioned are some and far from all grouped definitions. Although the definitions might appear slightly different at first sight but they share common aspects among them. First, they all involve some sort of interaction, relationship or connection between the customer and the brand or company. Second, they all involve engagement which is a state of attention by the customer that is the customer is absorbed, engrossed or involved or interested in the brand or company or company activities (Conscious attention CA). Third, to get involved in an interaction there has to be some form of attitude by the customer usually a love for or a passion for the brand that is an emotion towards the brand. Yet, few researchers added that there can be a negative engagement with an organization or brand as Van Doorn et al. (2010). Fourth, the definitions talk about a form of action that could be an actual behavior whether on or off line. This behavioral aspect is the main concern of Marketing Science Institute (MSI, 2010) and other researchers as Van Doorn et al. (2010) and Bijmolt et al. (2010) and others. In this concern, Vivek et al. (2014) conducted in depth interviews concerning this "active" participation by customers on a convenience sample of 62 interviewees of whom the majority responded to a question of I enjoy... because... using verbs of actions like buying, shopping, using, hearing, working. Fifth, this action could be personal from customer to company or from customer to other present or potential customers that is a social dimension. The social dimension of CE can take several forms as support from one customer to other customers or to potential customers or directly to the firm in the form of advice as to how to modify or upgrade the offering or to other customers in the form of help in how to better use the offering or to promote the brand to others. Thus it includes a behavior towards the organization or brand or towards other customers or potential customers. Sixth, the researcher believes that $\mathrm{CE}$ and $\mathrm{CEB}$ complement each other as customer behavior in this respect is accompanied by or preceded by an attention first then attitude or feelings and emotions towards a brand thus according to Vivek et al. (2014) the dimensions or the constructs of CE which are conscious attention (CA), enthused/emotional participation (EP) and social connection make a logical sequence to which the element of behavior comes as the peak. Then behavior if positive further engages the customers. So it is a sort of cyclical or iterative relationship as there is an overlap between the behaviors and the outcomes that further re-enforce the engagement.

\subsection{CE and Other Marketing Concepts}

There could be some confusion and overlap between Customer Engagement and other recent marketing concepts. Vargo and Lusch (2008) discuss customer co-production in which the customer actually gets involved in presenting and producing the service or offering for themselves and in this case of co-production the customer's role is a basic part of the service or offering but in CE we are talking about an over and above (extra) behavior that is not part of the service offering or part of the buying transaction but is a behavior that is voluntary and that in most cases is positive and creates benefit to the organization or brand. Moreover, this extra role behavior could be online or offline. Vargo (2009) also presents the concept of service dominant logic (S-D) which he 
argues that it transcends previous concepts including relationship marketing (RM) in a relationship between the customer and organization that is interactive, collaborative and reciprocal in a network process of value co-creation.

Following the same line of thought Vivek, Beatly and Morgan (2012) point out that Relationship Marketing is more concerned with retention of existing customers than with acquisition of new customers. According to Brodie et al. (2011) if both concepts of relationship marketing (RM) and service dominant logic are combined with $\mathrm{CE}$ then a more holistic approach of current and potential customers interacting together and interacting with the brand and other stakeholders which leads to "value configuration".

Other related concepts in marketing literature that include customer voluntary behaviors is customer citizenship behaviors as in Rosenbaum and Massiah (2007) which overlaps to a high degree with CE yet in customer citizenship behaviors the main concentration is on customer benevolent behaviors that are assigned and planned and designed by the organization thus the customer is behaving in accordance with the plans of the firm but CEB takes a wider bird eye's view where the customer behavior is driven by the customer and it is unique rather than planned by the firm on one hand. On the other hand, CEB could be positive that is beneficial for the organization or could be unbeneficial towards the firm (Brodie et al., 2013; Van Doorn et al., 2010).

\subsection{Types of Customer Engagement Behaviors (CEB)}

Kumar et al. (2010) propose a 4 components measurement of CE value that include customer lifetime value (purchase behavior), referrals, word of mouth (WoM) and knowledge value which is feedback about company products. As such, Kumar et al. (2010) include the purchase transaction, while most other papers including MSI define CEB as behavior beyond the purchase transaction. As such CEB can take different forms that include but not restricted to:

1) Customers' contribution in product development and innovations. Customers can modify and or augment a service offering. Customers can advise and/or help a service employee to better perform the job.

2) Customers' resource contribution of time, effort and monetary contributions towards the firm or brand.

3) Customers can affect other stakeholders' perception, expectations and preferences.

4) Customers can support other users in the service experience example students can help weaker ones in group work (peer learning). Customers can provide helpful advice to other users facing problem or to potential users who could be withdrawing from the intention to buy.

5) Customers can promote the company's products/services/brands to other present or potential customers' positive word of mouth (WoM) online or offline.

6) Cross-buying and opting for other products related to the brand or organization.

7) Blogging and web posting and writing reviews.

8) Recommendations and referrals.

To sum up, CEB goes beyond the purchase behavior to include other behaviors of the customers towards the brand/firm or towards other users or potential users or the society as a whole. These behaviors are voluntary by the customer and could be positive or negative for the organization and unique to the customer that is not planned by the organization.

\subsection{Factors Affecting $C E B$}

Why customers engage in those behaviors?

Some papers handled reasons why customers engage in behaviors beyond buying transactions. Fuller (2010) conducted an empirical study in virtual context in which it is argued that customers engage in CEB waiting for certain benefits as cost savings as for example getting the best deal for a vacation or social and esteem benefits as gained reputation online or gained knowledge of s specific area. Kwumar et al, (2010) added that companies could encourage positive CEB by enhancing their virtual platform to allow more customers to engage. Thus firms can even reward contributors for their effort in writing blogs or reviews by offering various economic rewards. Moreover, in case of universities, alumni meetings and other similar events can encourage communication among customers. Anderson and Mittal (2000), De Matos and Rossi (2008) and Van Doorn et al. (2010) emphasize attitudinal factors as a reason for CEB including satisfaction, commitment and value perception, where extreme levels of these factors whether very high or very low can emerge CEB that could be positive or negative. Van Doorn et al. also add the characteristics and personality and qualities of the customer can encourage CEB so that customers with high moral identity are more likely to help others and engage in 
useful support to others. Furthermore, the emotional state of the customer can encourage CEB especially if the customer is in a state of despair, disappointment, anger or regret this can surely lead to negative CEB as negative word of mouth (WoM) or negative blogging (Gregoire, Tripp, \& Legoux, 2009). Examples include a customer who leaves his pet in a pet service hotel and something happens to the pet can lead to negative WoM and such upset customers can become the brand's "worst enemies". Other factors affecting CEB include the strength of the brand that boosts CEB based on the fact that strong brand equity leads to stronger brand attachment which motivates engagement.

\subsection{Outcomes of $C E B$}

According to Jaakkola and Alexander (2014), outcomes of CEB include favorable results as satisfaction with the brand, trust and commitment towards the brand and communication among customers adds value to the firm. Hoyer et al. (2010) add that CE adds to product development and increases product benefits. Brodie et al. (2011) argue that positive consequences of CE include favorable WoM. Jaakkola and Alexander (2010) argue that CEB add a range of resources to the firm so that engaged customers devote time, money and actions to the brand which affects the organization in question whether directly or indirectly. Customer's sense of ownership of the offering and empowerment are key drivers to CEB (Jaakkola \& Alexander, 2014).

According to Van Doorn et al. (2010) the consequences of CEB are divided to consequences for the customers and consequences for the firm. As for the customers, CE has cognitive, attitudinal and behavioral outcomes and they all show a cyclical effect so that customers who engage in these behaviors and these behaviors are successful will lead to customers further engaging in similar and other behaviors. Moreover, CEB can have positive consequences for the firm as positive WOM behaviors and positive reviews and blogging will lead to disseminating information and attracting new customers. Furthermore, engaged customers enhance the brand in the long run. Engaged customers help firms in many ways both in the short and long run through a variety of activities as innovative ideas, improving existing services by helping other customers, convincing potential customers and other stakeholders such as quality bodies about the value of the brand. In this study, the researcher handles three outcomes of CEB which are benevolence, affective commitment and future patronage.

\subsubsection{Benevolence/Trust}

According to Martinez and Rodriguez Del Bosque (2013) consumer trust is the belief by the customer that a specific service or product can be depended on and function in the interest of the customer. Sirdesmukh et al. (2002) divides trust into credibility trust and benevolence trust where benevolence trust is when consumers have the feeling that the organization honestly cares about the customer's well-being and not only act in an ethical reliable method but also puts the benefit and interest of the customer in all decisions regarding services provided. Ball et al. (2004) emphasize that trust depends on the existence of organizational values that are shared with the customers. Trust is enhanced when all organizational actions are credible beyond any contractual or legal constraints (Swean \& Chumpitaz, 2008).

Trust has been widely studied in marketing literature. In general, trust can be defined as the confidence and belief of one party that the other party is honest and reliable (Mosavi \& Ghaedi, 2012). Trust can be directed by the customer to the sales person sales representative or to the institution or the brand (higher education institution) (Rauyruen \& Miller, 2007). This second type of trust towards the organization is the one in question in this study.

Moreover, Doney, and Cannon, (1997) separate 2 dimensions of trust: the first dimension of trust is related to credibility of the organization which in our case means that the student expects he/she can rely on the university's word or written promise. The second dimension is Benevolence which means to what extent the student feels that the university is after the benefit and good of the student's welfare and that the university doesn't look after its own welfare only but after the joint benefit of the students and the university together. In the context of services trust is regarded as necessary for building a long-term relationship with the brand.

\subsubsection{Affective Commitment}

Commitment is when the customer wants to carry on a beneficial relationship with the brand (Mosavi \& Ghaed, 2012). It is also mentioned that in services, relationships are maintained basically on mutual commitment. Commitment can be also viewed as a measure of potential profits and thus as an indicator for organizational performance. Keh and Xie (2009) explain commitment as the desire of the customer to maintain a long-term relationship with the organization. Many researchers argue that customer commitment depends on the extent to which the organization makes an effort to maintain the mutual relationship (Bennett, 1996). Thus for any organization, commitment is important for long-term relationships with the customer.

Meyer and Allen (1997) divided commitment of employees to the organization in which they work into 3 parts, 
affective, normative and continuance commitment. Yet this model can be extended to commitment of customers towards a brand or organization. Bansal, Irving, and Taylor (2004) explain affective commitment as the force that binds the consumer to the brand out of love and desire, while normative is tying the customer to the brand out of obligation, which is less realistic and the third is continuance commitment which binds the customer to the brand out of need due to high switching cost or to unattractive choices (Bansal, Irving, \& Taylor, 2004). Keiningham et al. (2015) ensure that affective commitment is an emotional and internal psychological commitment, while normative commitment emerges from feeling of obligation thus has a social dimension, while calculative commitment is based on an economic and materialistic dimension. Here, affective commitment is strongly tied to repurchase intentions or future patronage.

In all cases commitment is the force that joins the student to the university in long-lasting relationship.

\subsubsection{Future Patronage}

Future patronage or repurchase intention refers to the desire of the consumer to future buy from the same brand or the same organization. Future patronage is based on the willingness of a customer to buy more from the same organization or brand (Mosavi \& Ghaedi, 2012). This decision to rebuy goes hand in hand with Benevolence/Trust and affective commitment that a customer has for the brand. Future patronage could be defined as a behavioral intention to rebuy, navigate other products or cross buying other products of the firm (Ha et al., 2010). Repurchase intention is based on the judgment of the customer towards the brand at a point in time when the customer makes this intention and the circumstances of the customer at that point of time (Lacey \& Morgan, 2009).

According to Jarvenpaa et al. (2000) customer trust based on affective commitment is a very important reason that leads to customer's future repurchase intentions (Jarvenpaa et al., 2000).

\section{Research Problem}

From the review of literature it can be seen that many of papers related to $\mathrm{CE}$ are devoted to refining the understanding of the concept of $\mathrm{CE}$, its dimensions, antecedents and outcomes and are conceptual in nature (Mollen \& Wilson, 2010; Van Dorn et al., 2010; Kumar et al., 2010; Brodie et al., 2011; Hollebeedk, 2011).

While the focus of other papers is empirical in nature (Gambetti et al., 2012; Hollebeek \& Chen, 2014; Jaakkola \& Alexander, 2014; Vivek et al., 2014). Yet, many of the empirical research measures consumer engagement in online brand communities (Gummerus et al., 2012; Calder et al., 2009; Dessart et al., 2015). Thus from the review of literature we can see that customer engagement research was initially conceptually directed due to lack of total agreement over the conceptual domain of engagement and many of the empirical papers that follow, concentrate on engagement of customers with online or virtual medium, as such there is a gap that allowed me as a researcher to attempt an empirical study where the area of application is not online but rather in higher education context. The study aims to measure the CE of students and the impact of CE and CEB on student benevolence, affective commitment and future patronage towards their university.

\section{Purpose and Contribution of This Research}

The purpose of this paper is to investigate through an empirical research the relationship between CEB and some of its alleged outcomes that include Benevolence/Trust, affective commitment and future patronage in a service sector which is Higher Education.

Contribution of this research and area of application:

Empirically, this article studies CE in an offline perspective as compared to several other articles that study CEB in virtual environment. Moreover, this research investigates CEB in a university setting. Thus the area of application is a service sector in a higher education institution as compared to other services as fitness centers, gyms, spas and other. Higher Education (H. E.) is now facing considerable change and turbulence, especially in developing economies as Egypt, which after two revolutions is in the process of upgrading its education provision from its roots. Moreover, with the allowance of private universities in Egypt the competition has become a challenge for $\mathrm{H}$. E. Institutions that strive to develop a competitive edge to differentiate them from other higher education institutions especially that private universities in Egypt are gaining position now (Barsoum, 2014). It is about time for H.E institutions to realize that customers (students) can add value to their brand in several different behaviors beyond the buying decision. These behaviors are of great value to the institution (Brand) if positive and can be well employed to serve the institution to create required out comes of Benevolence/Trust, future patronage and affective commitment of present and potential students which is a more effective way to retain existing students and attract new ones rather than other means of spending on retaining and attracting students. CEB if well managed and nurtured by H. E institution managers can help in building a 
sustainable competitive advantage for the university.

Moreover, in this research the researcher combines in the empirical study the construct of CE with its components as well as other CEB.

\section{Research Objective, Questions and Hypotheses}

\subsection{Research Objective}

Customers can create value for an organization through behaviors beyond the buying transaction. These behaviors can take place only when customers are engaged and this leads to favorable outcomes including among others favorable outcomes Benevolence/Trust, future patronage and affective commitment of the customers. As such, organizations have become interested in CEB and realize the need to study CE and how to measure CEB. The objective of this research is to investigate the concept of CEB and to suggest a model that depicts $\mathrm{CE}$ and various CEB and some of its favorable outcomes.

\subsection{Research Questions}

1) Do engaged customers who are characterized by being intrigued or interested in the brand and or have an emotional feeling towards the brand take one step further and start to behave in a way that adds to the service or the brand and attract new customers?

2) To what extent conscious attention (CA) leads to CEB?

3) Does enthused / emotional participation (EP) lead customer to make certain behaviors (CEB)?

4) To what extent CEB leads to favorable outcomes of Benevolence (BEN), future patronage (FP) and affective commitment (AC)?

\subsection{Research Hypotheses}

H1: CA has a significant positive effect on CEB

H2: EP has a significant positive effect on CEB

H3: CEB has a significant positive effect on Ben

H4: CEB has a significant positive effect on FP

H5: CEB has a significant positive effect on AC

H6: CEB mediates the relationship between CA and a) Ben, b) FP, and c) AC

H7: CEB mediates the relationship between EP and a) Ben, b) FP, and c) AC

\section{Methodology}

\subsection{Research Approach and Population}

The researcher resorted to the case study approach which is convenient for exploratory investigations as the concept is not very clearly developed and is somewhat blurred. The case study is conducted on October University for Modern Sciences and Arts (MSA) which is one of 23 private universities in Egypt (Ministry of Higher Education-Egypt, 2017). MSA has 9 faculties as follows: Arts and Design, Biotechnology, Computer Science, Dentistry, Engineering, Languages, Management Sciences, Mass Communication and Pharmacy with around 10,000 students in all faculties. Thus the population of the research includes students of private universities in Egypt.

\subsection{Data Collection and Sample}

The sample used is a convenience sample where self-administered questionnaires were distributed to 300 students. According to Sekaran and Bougie (2009) a convenience sample is gathering information from the population elements who conveniently happen to be available to provide it. It is a non-probability sampling technique which can be inexpensive and quick and sometimes the only way to obtain information, and can offer potentially useful and practical information.

Five out of the nine faculties of MSA University were selected as the other four faculties had oral or practical exams at the time of data collection and thus the students were not available for the research. The 5 selected faculties were Management Sciences, Biotechnology, Pharmacy, Mass Communication and Art \& Design.

The questionnaires were distributed equally among the 5 faculties with 60 questionnaires for students of each faculty aiming at students of year 2, 3 and 4 thus avoiding year one as students in year one might not be highly familiar with their university. 
The questionnaires were distributed starting Saturday 28 April 2018 in the morning till Thursday 10 May 2018 in the afternoon at 2:00 pm. The questionnaires were distributed to students of level 2, 3, and 4 on week days from Saturday to Thursday avoiding Friday (holiday).

The response rate was almost $86 \%$ with 257 completed questionnaires as around 20 questionnaires were not completed and were removed of these completed questionnaires, 130 questionnaires were responded by male students (50.6\%) and 127 females (49.4\%) almost equal to avoid any gender bias. The questionnaires were distributed by the help of teaching assistants of various levels in each of the five faculties ensuring that there is no overlap that a student can answer the questionnaire twice.

\subsection{Research Variables and Measurement Instrument}

Following previous review of literature the researcher assumes that $\mathrm{CE}$ is measured by 2 dimensions: conscious attention (CA) and emotional participation (EP) as for the third dimension of Vivek et al. (2014) the researcher didn't include it as a separate construct because according to (Vivek et al., 2014) contrary to the theoretical literature the social connection dimension was not significant in their assessment which required further investigation by research. Moreover, the researcher in this study decided to separate actions as a moderator between $\mathrm{CE}$ which includes interest and feeling from CEB which most papers ensure that it is behaviors beyond the buying transactions towards a brand or offering.

Yet the model of this research combines both as previously mentioned and it is hypothesized that CE leads to CEB which in turn leads to the required outcomes of Benevolence/Trust, affective commitment and intent of future patronage or cross buying.

The researcher used a self-administered questionnaire on a convenience sample in one private university in Egypt which is October University for Modern Sciences and Arts (MSA). The questions of the data collection tool use a 5-point Likert Scale to measure all dependent (Endogenous) and independent (Exogenous) variables except for the gender question. Most constructs were measured using previously tested measures based on previous literature to ensure their validity as according to Sekaran and Bougie (2009) when well validated measures are used, a researcher can be more confident of their validity, yet the researcher also tested both validity and reliability as indicated later in section 7 of this research. All variables and constructs are indicated in Table 1.

Table 1. The research constructs and variables/with their sources

\begin{tabular}{|c|c|c|}
\hline Construct & Variable & Source \\
\hline \multirow{3}{*}{$\begin{array}{l}\text { Conscious Attention } \\
\text { (CA) }\end{array}$} & 1. Anything related to MSA grabs my attention. & Vivek et al. (2014) \\
\hline & 2. I like to learn more about MSA. & Vivek et al. (2014) \\
\hline & 3. I like events that are related to MSA. & Vivek et al. (2014) \\
\hline \multirow{3}{*}{$\begin{array}{l}\text { Enthused/Emotional } \\
\text { Participation (EP) }\end{array}$} & 4. I am passionate about my university MSA. & Vivek et al. (2014) \\
\hline & 5. I try to fit MSA events into my schedule. & Vivek et al. (2014) \\
\hline & 6. I enjoy spending time at MSA. & Vivek et al. (2014) \\
\hline \multirow{7}{*}{$\begin{array}{l}\text { Customer Engagement } \\
\text { Behavior (CEB) }\end{array}$} & 7. I mention MSA to others quite frequently. (WoM) & Harrison-Walker (2001) \\
\hline & 8. I seldom miss an opportunity to tell others about my university MSA. (WoM) & Harrison-Walker (2001) \\
\hline & $\begin{array}{l}\text { 9. I am ready and willing to put more time and effort to help enhance and improve my } \\
\text { university. (WoM) }\end{array}$ & Harrison-Walker (2001) \\
\hline & 10. I am willing to blog and answer any queries and comment about MSA in social media. & Vivek et al. (2014) \\
\hline & $\begin{array}{l}\text { 11. I am willing to defend MSA if any one wrongly accused it even if requires some time } \\
\text { and effort. }\end{array}$ & Vivek et al. (2014) \\
\hline & $\begin{array}{l}\text { 12. I am willing to help other students (my peers) to allow them to make the best benefit, in } \\
\text { their experience at MSA and enjoy. }\end{array}$ & Vivek et al. (2014) \\
\hline & 13. I am ready to make suggestions that will improve MSA and how it serves the students. & Vivek et al. (2014) \\
\hline \multirow{3}{*}{$\begin{array}{l}\text { Benevolence/Trust } \\
\text { (BEN) }\end{array}$} & 14. I think MSA always tries to do the right things for its students. & Bove et al. (2009) \\
\hline & 15. I think MSA has a true and genuine care and concern for its students. & Bove et al. (2009) \\
\hline & 16. I think that MSA puts extra effort to serve its students. & Bove et al. (2009) \\
\hline \multirow[t]{2}{*}{$\begin{array}{l}\text { Future Patronage } \\
\text { Repurchase Intent (FP) }\end{array}$} & 17. I intend to continue my undergraduate degree with MSA. & $\begin{array}{l}\text { Mathwick, Malhotra, and } \\
\text { Rigdon (2001) }\end{array}$ \\
\hline & $\begin{array}{l}\text { 18. If I am planning to take any future post graduate studies or professional studies as a } \\
\text { diploma, MA, MBA, MSC, DBA or just professional courses, the first place I will think of } \\
\text { is MSA if it offers these degrees. }\end{array}$ & $\begin{array}{l}\text { Mathwick, Malhotra, and } \\
\text { Rigdon (2001) }\end{array}$ \\
\hline $\begin{array}{l}\text { Affective Commitment } \\
\text { (AC) }\end{array}$ & $\begin{array}{l}\text { 19. I feel emotionally attached to MSA. } \\
\text { 20. With MSA, it feels like I am part of a family. } \\
\text { 21. I feel a sense of belonging with my university MSA. }\end{array}$ & $\begin{array}{l}\text { Bansal, Irving, and Taylor } \\
\text { (2004) Bansal, Irving, and } \\
\text { Taylor (2004) }\end{array}$ \\
\hline
\end{tabular}

Note. The scale is: $1=$ strongly disagree; $2=$ disagree; $3=$ neither agree nor disagree; $4=$ agree; $5=$ strongly agree. 


\section{Data Analysis and Results}

In order to test the direct and indirect relationships, researcher adopts the Structure Equation Modeling (SEM) analysis. SEM can be conducted using Covariance Based CB-SEM or Partial Least Squares PLS-SEM. (Hair et al., 2011; 2014; 2016). There are many differences between CB-SEM and PLS-SEM.

Hair et al. $(2011 ; 2014 ; 2016)$ state that there are certain assumptions for selection between two types of SEM so that if the goal of the researcher is comparison of alternative theories then CB-SEM is the better choice, but if there is an existing structural theory then PLS-SEM is better. If the structural model is complex (many constructs and many indicators), select PLS-SEM. If the researcher needs to use latent variable scores in subsequent analyses, PLS-SEM is the best approach.

With regards to the sample size according to Hair et al. (2014), the minimum sample size should be more than 10 times of the relationships directed to a dependent variable, which applies to this research.

Therefore, in order to test the abovementioned hypotheses, Partial Least Squares Structural Equation Modeling (PLS-SEM) is employed in order to test the complicated model, develop or at least update an existing theory, and explore new relationships by testing the proposed hypotheses. PLS-SEM is applied using Smart PLS v. 3.2.7 (Ringle et al., 2015). The researcher followed SEM two-stage approach in implementing SEM. First approach is directed to measurement evaluation. Then, Structural model evaluation will be the second stage (Hair et al., 2016).

First, the results of improved measurement model evaluation are presented in Table 2. As can be seen from Table 2, all items' reliabilities (loadings) are $>0.708$ except CEB 7 which has 0.699 item loading but the other items at the same construct have high item loadings that can substitute CEB7 item loading decrease.

Also, all constructs convergent validity is $\geq 0.5$. All constructs' composite reliabilities (CR) and Cronbach's alpha are $>0.6$. This indicates that all measurements of research variables are reliable and can be used for testing the research hypotheses.

Next, to evaluate the discriminant validity among the current constructs, Fornell Larcker Criterion was applied to test the discriminant validity as can be seen in Table 3. Since each construct's AVE is higher than its squared correlation with other constructs at the current research model, discriminant validity is established (Hair et al., 2014; 2016).

Moreover, all measurement items violate the normality assumption since each of skewness or kurtosis are not zero for each item. However, research can process with the inferential statistics because the violation of normal distribution is too small and between the range of common violation in social science (e.g., skewness $-3:+3, \&$ Kurtosis -10:+10) (Kline, 2015). In addition, the researcher applied PLS-SEM which is a non-parametric analysis that can work accurately with nonrandom data (Hair et al., 2014). This is also why the researcher resorted to PLS-SEM which is a better choice than CB-SEM if the data are to some extent non-normal (Hair et al., 2014). 
Table 2. Measurement model evaluation

\begin{tabular}{|c|c|c|c|c|c|c|c|c|c|c|c|c|c|}
\hline \multirow{2}{*}{ Cons } & \multirow{2}{*}{ AVE } & \multirow{2}{*}{$\mathrm{CR}$} & \multirow{2}{*}{$\begin{array}{l}\text { Cronbach's } \\
\text { Alpha }\end{array}$} & \multicolumn{4}{|l|}{ VIF } & \multirow{2}{*}{ Indicator } & \multirow{2}{*}{ Outer loading } & \multicolumn{4}{|c|}{ Descriptive statistics } \\
\hline & & & & CEB & Ben & $\mathrm{FP}$ & $\mathrm{AC}$ & & & Mean & Std. & Skewness & Kurtosis \\
\hline \multirow[t]{3}{*}{$\mathrm{AC}$} & 0.809 & 0.927 & 0.881 & NA & & & & $\mathrm{AC} 1$ & 0.873 & 3.61 & 1.048 & -.467 & -.319 \\
\hline & & & & & & & & $\mathrm{AC} 2$ & 0.915 & 3.71 & 1.052 & -.648 & -.043 \\
\hline & & & & & & & & $\mathrm{AC} 3$ & 0.910 & 3.73 & 1.083 & -.763 & .178 \\
\hline \multirow[t]{3}{*}{ Ben } & 0.777 & 0.912 & 0.856 & NA & & & & Ben1 & 0.889 & 3.89 & 1.007 & -.805 & .275 \\
\hline & & & & & & & & Ben2 & 0.916 & 3.60 & 1.149 & -.563 & -.386 \\
\hline & & & & & & & & Ben3 & 0.838 & 3.54 & 1.031 & -.494 & -.133 \\
\hline \multirow[t]{3}{*}{$\mathrm{CA}$} & 0.666 & 0.857 & 0.749 & 1.98 & NA & & & CA1 & 0.787 & 3.50 & 1.054 & -.455 & -.350 \\
\hline & & & & & & & & CA2 & 0.870 & 3.54 & 1.104 & -.468 & -.432 \\
\hline & & & & & & & & CA3 & 0.788 & 3.74 & 1.003 & -.716 & .177 \\
\hline \multirow[t]{7}{*}{ CEB } & 0.558 & 0.898 & 0.867 & NA & 1.00 & & & CEB1 & 0.702 & 3.47 & .982 & -.301 & -.215 \\
\hline & & & & & & & & CEB2 & 0.710 & 3.76 & .943 & -.628 & .410 \\
\hline & & & & & & & & CEB3 & 0.798 & 3.52 & .979 & -.492 & .098 \\
\hline & & & & & & & & CEB4 & 0.789 & 3.75 & .932 & -.590 & .194 \\
\hline & & & & & & & & CEB5 & 0.795 & 3.92 & .922 & -.657 & .102 \\
\hline & & & & & & & & CEB6 & 0.729 & 3.95 & .918 & -.739 & .399 \\
\hline & & & & & & & & CEB7 & 0.699 & 3.72 & 1.005 & -.612 & .142 \\
\hline \multirow[t]{3}{*}{ EP } & 0.638 & 0.841 & 0.717 & 1.98 & NA & & & EP1 & 0.840 & 3.48 & 1.122 & -.428 & -.559 \\
\hline & & & & & & & & EP2 & 0.775 & 3.62 & 1.126 & -.758 & -.024 \\
\hline & & & & & & & & EP3 & 0.779 & 3.63 & .907 & -.547 & .318 \\
\hline \multirow[t]{2}{*}{ FP } & 0.745 & 0.854 & 0.657 & NA & & & & FP1 & 0.861 & 3.59 & 1.043 & -.450 & -.310 \\
\hline & & & & & & & & FP2 & 0.865 & 3.68 & 1.046 & -.587 & -.001 \\
\hline
\end{tabular}

Note. $1 . \mathrm{AVE}=$ Average Variance Extracted; $2 . \mathrm{CR}=$ Composite reliability.

Table 3. Discriminant validity via fornell-larcker criterion

\begin{tabular}{lllllll}
\hline Constructs & AC & Ben & CA & CEB & EP & FP \\
\hline AC & 0.899 & & & & & \\
Ben & 0.570 & 0.881 & & & & \\
CA & 0.600 & 0.575 & 0.816 & & & \\
CEB & 0.689 & 0.588 & 0.648 & 0.747 & & \\
EP & 0.652 & 0.589 & 0.704 & 0.678 & 0.799 & \\
FP & 0.627 & 0.540 & 0.557 & 0.616 & 0.568 & 0.863 \\
\hline
\end{tabular}

In Table 3 the diagonal values are the square root of AVE of the constructs and the other values are the coefficient correlation between constructs, where the square root of AVE (diagonal) are higher than values under and to the left which proves discriminant validity.

The measurement model constructs are valid and reliable. Moreover, the Variance Inflation Factor (VIF) values of independent constructs $(\mathrm{CA}=1.98, \mathrm{EP}=1.98 \& \mathrm{CEB}=1.00)$ are way less than the threshold limit of 5 (acceptable between 0.2 and 5 as per Hair et al., 2014). Therefore there is NO multicollinearity problem between the independent constructs. Thus, structural model assessment can be started as the second stage. 


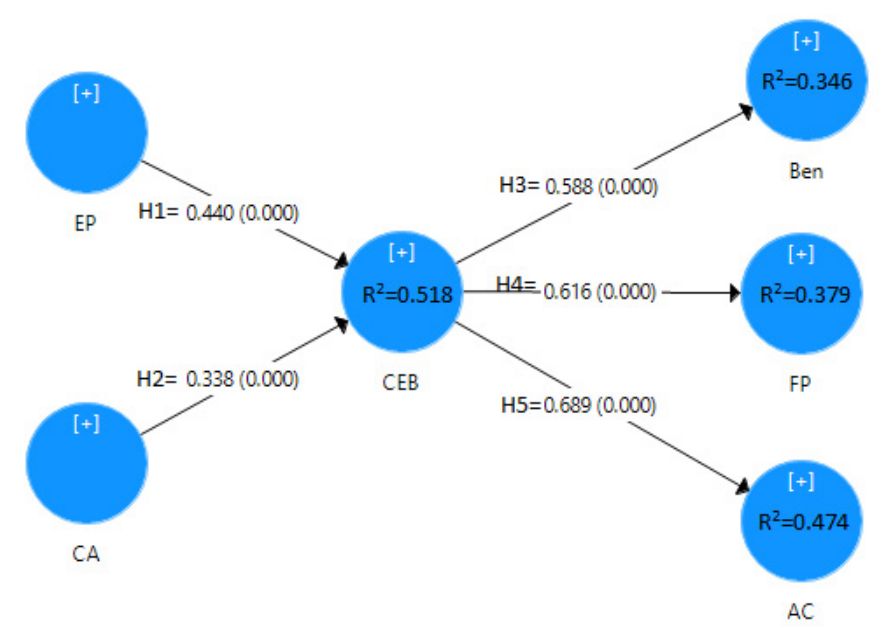

Figure 1. Suggested research model

Figure 1 illustrates variance coefficient as well as hypotheses testing results. All variance coefficients $\left(\mathrm{R}^{2}\right)$ for CEB and its consequences are moderate $(0.25 \%$ to $0.75 \%)$ (Hair et al., 2014$)$.

As can be seen from Figure 1, all direct research hypotheses are significantly supported at $99.9 \%$ confidence level. Therefore:

- CA has a significant positive effect on CEB by 0.338 , which means increasing CA by one unit will increase CEB by $33.8 \%$ unit thus $\mathrm{H} 1$ is supported.

- EP has a significant positive effect on CEB by 0.44, which means increasing EP by one unit will increase CEB by $44 \%$ unit thus $\mathrm{H} 2$ is supported.

- CEB has a significant positive effect on Ben by 0.588 , which means increasing CEB by one unit will increase Ben by $58.8 \%$ unit thus $\mathrm{H} 3$ is supported.

- CEB has a significant positive effect on FP by 0.616 , which means increasing CEB by one unit will increase FP by $61.6 \%$ unit thus $\mathrm{H} 4$ is supported.

- CEB has a significant positive effect on AC by 0.689 , which means increasing CEB by one unit will increase $\mathrm{AC}$ by $68.9 \%$ unit thus $\mathrm{H} 5$ is supported.

In addition, the whole model can explain the change in CEB by $51.8 \%$ which is moderate coefficient. As well as . the whole model can explain the change in Ben, FP and AC by $34.6 \%, 37.9 \%$ and $47.4 \%$ respectively.

With respect to the mediation analysis, the researcher followed Preacher and Hayes $(2004 ; 2008)$ approach as illustrated in Nitzl et al. (2016).

Firstly, the direct relationships from EP and CA, without CEB, should be significant as demonstrated in step (1) (see Table 4). Both betas are significantly accepted.

Secondly, the significant relationships in step (1) will be proceeded in step (2) where the mediator role is included in the model.

Next, the indirect relationships from the two abovementioned exogenous variables on Ben, FP, and AC should be significant. All indirect effects are significant.

Step (3) procedure includes testing the total effect from all exogenous variables on endogenous variables.

Finally, the researcher calculates the Variance Accounted For (VAF) value to determine exactly the effect size of the mediator though dividing the sig. indirect relationship by sig. total effect.

VAF value indicates one of the three levels of mediation. If VAF is less than 0.2 , the relationship is not mediated and if the value is form $0.2-0.8$, the relationship is partially mediated. Finally, if VAF is higher than 0.8 , the relationship is fully mediated (Hair et al., 2014; Hayes, 2013). 
Table 4. Mediation analysis

\begin{tabular}{|c|c|c|c|c|c|c|c|}
\hline \multirow[t]{5}{*}{ Step (1) } & \multicolumn{7}{|c|}{ Direct Path coefficients without mediator } \\
\hline & Path & \multicolumn{2}{|c|}{$\beta^{(S i g) .}$} & \multicolumn{2}{|l|}{ Path } & \multicolumn{2}{|l|}{$\beta^{(\text {Sig }) .}$} \\
\hline & EP - > Ben & \multicolumn{2}{|l|}{$0.357^{(0.000)}$} & \multicolumn{2}{|l|}{$\mathrm{CA}->$ Ben } & \multicolumn{2}{|l|}{$0.330^{(0.000)}$} \\
\hline & $\mathrm{EP}->\mathrm{FP}$ & \multicolumn{2}{|l|}{$0.343^{(0.000)}$} & \multicolumn{2}{|l|}{$\mathrm{CA}->\mathrm{FP}$} & \multicolumn{2}{|l|}{$0.322^{(0.000)}$} \\
\hline & $\mathrm{EP}->\mathrm{AC}$ & \multicolumn{2}{|l|}{$0.446^{(0.000)}$} & \multicolumn{2}{|l|}{$\mathrm{CA}->\mathrm{AC}$} & \multicolumn{2}{|l|}{$0.288^{(0.000)}$} \\
\hline \multirow[t]{4}{*}{ Step (2) } & \multicolumn{7}{|c|}{ Indirect Path coefficients with the mediator=(exogenous to mediator. mediator to endogenous) } \\
\hline & Path & \multicolumn{2}{|l|}{$\begin{array}{l}\text { Ben } \\
\beta^{\text {(Sig). }}\end{array}$} & \multicolumn{2}{|l|}{$\begin{array}{l}\text { FP } \\
\beta^{(S i g) .}\end{array}$} & \multicolumn{2}{|c|}{$\begin{array}{l}\mathrm{AC} \\
\beta^{(\text {(sig). }}\end{array}$} \\
\hline & EP & \multicolumn{2}{|l|}{$0.236^{(0.000)}$} & \multicolumn{2}{|l|}{$0.289^{(0.000)}$} & \multicolumn{2}{|l|}{$0.311^{(0.000)}$} \\
\hline & $\mathrm{CA}$ & \multicolumn{2}{|l|}{$0.235^{(0.000)}$} & \multicolumn{2}{|l|}{$0.281^{(0.000)}$} & \multicolumn{2}{|l|}{$0.331^{(0.000)}$} \\
\hline \multirow[t]{4}{*}{ Step (3) } & \multicolumn{7}{|c|}{ Total Path coefficients with the mediator $=($ Direct + Indirect effect $)$} \\
\hline & Path & \multicolumn{2}{|l|}{$\begin{array}{l}\text { Ben } \\
\beta^{-(S i g) .}\end{array}$} & \multicolumn{2}{|l|}{$\begin{array}{l}\text { FP } \\
\beta(\text { Sig). }\end{array}$} & \multicolumn{2}{|l|}{$\begin{array}{l}\mathrm{AC} \\
\beta^{-(\text {(Sig). }}\end{array}$} \\
\hline & EP & \multicolumn{2}{|l|}{$0.590^{(0.000)}$} & \multicolumn{2}{|l|}{$0.569^{(0.000)}$} & \multicolumn{2}{|l|}{$0.651^{(0.000)}$} \\
\hline & $\mathrm{CA}$ & \multicolumn{2}{|l|}{$0.581^{(0.000)}$} & \multicolumn{2}{|l|}{$0.562^{(0.000)}$} & \multicolumn{2}{|l|}{$0.604^{(0.000)}$} \\
\hline Step (4) & Mediation & ct Vairance & ccounted For VAF & irect effect/Tc & tal effect) & & \\
\hline & & Ben & & FP & & $\mathrm{AC}$ & \\
\hline & Path & $V A F$ & Decision & $V A F$ & Decision & $V A F$ & Decision \\
\hline & EP & 0.4 & Partial mediation & 0.508 & Partial mediation & 0.478 & Partial mediation \\
\hline & $\mathrm{CA}$ & 0.404 & Partial mediation & 0.5 & Partial mediation & 0.548 & Partial mediation \\
\hline
\end{tabular}

The indirect research hypotheses are partially supported at confidence level $99.9 \%$.

- H6a means CEB partially mediates the relationship between CA and Ben by 0.404 . This means CEB can explain the relationship between CA and Ben by $40.4 \%$.

- H6b means CEB partially mediates the relationship between CA and FP by 0.5 . This means CEB can explain the relationship between CA and FP by $50 \%$.

- H6c means CEB partially mediates the relationship between CA and AC by 0.548 . This means CEB can explain the relationship between CA and AC by $54.8 \%$.

Moreover,

- H7a means CEB partially mediates the relationship between EP and Ben by 0.4. This means CEB can explain the relationship between EP and Ben by $40 \%$.

- H7b means CEB partially mediates the relationship between EP and FP by 0.508 . This means CEB can explain the relationship between EP and FP by $50.8 \%$.

- H7c means CEB partially mediates the relationship between EP and AC by 0.478 . This CEB can explain the relationship between EP and AC by $47.8 \%$.

\section{Conclusion and Managerial Implication}

From the above supported hypotheses and model, it can be concluded that the 2 constructs that bring forth customer engagement, which are conscious attention (CA) and enthused participation (EP) actually lead to CEB, which are behaviors beyond the buying of the product. Managers of universities, especially private universities in Egypt where the marketization of higher education has created tough competition, need to be aware that these behaviors can benefit the organization or the brand in many ways. First by acting to increase the university's resources through students who ready to devote time and effort to help other students who could have faced hardships in absence of this student to student support or who could have been replaced by employees who might not be as enthusiastic to help their weaker fellow colleagues and who could have cost the university added expenses with lower quality outcomes. Second, engaged students spend time to blog write reviews and spread positive WoM to potential customers to persuade them to join and to existing customers who were about to switch to change their minds. Thus, they can act to promote their university in a way that is more credible to convince potential customers in a less expensive way than spending on the promotion of the university in media as newspapers that have a wide distribution. Third, engaged students can help to improve their university by offering constructive criticism and suggestions for improvement and take an active rather than a passive attitude. Fourth, engaged students can act as ambassadors who speak in favor of their university when it comes to dealing with quality bodies, validation and accreditation boards and professional bodies (syndicates) or other thus they support their university in this regard and these bodies are extremely important for universities in Egypt to 
ensure validation by other international universities which indicate international acceptance and to ensure quality endorsement by quality bodies, professional bodies which all ends to the benefit of the university (brand) and the improvement of the brand image which in turn leads to a more prestigious positioning of the brand which attracts better quality intake of students.

The research model proves that engaged students who undertake CEB lead to the favorable required outcomes of affective commitment (AC), Benevolence/Trust (Ben) and future patronage (FP). Engaged students tend to be committed towards the university and according to Mettal, Sambandam and Dholakia (2010) customer commitment towards the brand has many favorable consequences which include but not restricted to higher tolerance towards to negative mishaps as product/service failure or corporate scandals. Moreover, commitment is considered a strong driver of repurchase intentions. Gustafisson; Johnson and Roos (2005) state that commitment can create "stickness" which retain students (customers) with the university. Moreover, CEB leads to trust which according to Ball et al. (2004) can be considered as a mediator between the brand and customers' repurchase intention which leads to maximum economic benefit to the brand. Finally, engaged students who perform CEB help organization in many ways both in the short and long run through various actions as innovative solutions to problems, improving services, helping other customers make use of the offered services, convincing potential customers to try the brand. Furthermore, CEB leads to the outcomes of trust, future patronage and affective commitment. Thus, higher education institutions can benefit from the model and try to measure and watch the level of CEB and its outcomes as an indicator to help the institution to maintain and attract new students in a highly competitive market and thus to use a more realistic way to grow and cut down on increased marketing spending to recruit and retain students. As such, higher education institutions can gain competitive advantage by enhancing and supporting favorable CEB. Petruzzellis and Romanazzi (2010) recommend universities to demonstrate the means by which they support their students which could be support from engaged student to student through favorable CEB. If universities really want to cope with competition in a recently fast changing market of education thus, they should reconsider the concept of value co-creation and the benefits of CEB in education.

\section{Limitations and Suggestions for Further Research}

This study is conducted in one private university in Egypt as a case study, and just like any case study it has the serious limitation which is we can't generalize the findings. This research should be conducted in other universities or other higher education institutions. The measurements of the model in the study indicate accepting the hypotheses but still it could be further applied to other institutions to further assess the goodness of the model. Given the fact that CEB and its outcomes are still in their infant stage as there is no complete understanding of the concept of $\mathrm{CEB}$ in students in higher education, thus it is a challenging area that require further investigation especially in Egyptian culture which has some differences from Western culture conducted in various international studies. Moreover, further investigation could handle other favorable outcomes of CEB as loyalty and even investigate the adverse outcomes of unfavorable behaviors as negative WoM or negative blogging.

\section{References}

Anderson, E., \& Mittal, V. (2000). Strengthening the satisfaction profit chain. Journal of Service Research, 3(November), 107-120. https://doi.org/10.1177/109467050032001

Ball, E., Coetho, P., \& Machas, A. (2004). The role of communication and trust in explaining customer loyalty: an extension to the ESCI Model. European Journal of Marketing, 38(9/10), 1272-1293. https://doi.org/10.1108/03090560410548979

Bansal, H., Irving, P., \& Taylor, S. (2004). A three-component model of customer commitment to service providers. Journal of the Academy of Marketing Science, 32(3), 234-250. https://doi.org/10.1177/0092070304263332

Barsoum, G. (2014). The challenges of private higher education in Egypt. Economic Research Forum, 833.

Bennett, R. (1996). Relationship information and governance in consumer markets: transactional versus the behaviorist approach. Journal of Marketing Management, 12(5), 417-436. https://doi.org/10.1080/0267257X.1996.9964425

Bijmolt, T., Leeflang, P., Block, F., Eisenbeiss, M., Hardie, B., \& Lemmen, A. (2010). Analytics for customer engagement. Journal of Service Research, 13(3), 341-356. https://doi.org/10.1177/1094670510375603

Bove, L., Prevan, S., Beatty, S., \& Shiu, E. (2009). Service worker role in encouraging customer organizational citizenship behaviors. Journal of Business Research, 62(7), 698-705. 
https://doi.org/10.1016/j.jbusres.2008.07.003

Brodie, R., Ilic, A., Juric, B., \& Hollebeek, L. (2013). Customer engagement in a virtual brand community: an exploratory analysis. Journal of Business Research, 66(1), 105-114. https://doi.org/10.1016/j.jbusres.2011.07.029

Brodie, R. J., Hollebeek, L., Juric, B., \& Ilic, A. (2011). Customer engagement: conceptual domain, fundamental propositions and implications for research. Journal of Service Research, 14(3), 252-274. https://doi.org/10.1177/1094670511411703

Byrne, B. (2010). Structural equation modeling with AMOS; basic concepts, applications, and programming (2nd ed.). Taylor and Francis Group, LLC.

Calder, B., Malthouse, E., \& Schaedel, U. (2009). An Experimental study of the relationship between online engagement and advertising effectiveness. Journal of Interactive Marketing, 23, 321-331. https://doi.org/10.1016/j.intmar.2009.07.002

Daire, H., Joseph, C., \& Michael, R. (2008). Structural Equation Modeling: Guidelines for determining model fit. Journal of Business Research Methods, 6(1).

De Bruyn, A., \& Lilien, G. (2008). A Multi-stage model of word-of-mouth influence through viral marketing. International Journal of Research in Marketing, 25(3), 151-163. https://doi.org/10.1016/j.jiresmar.2008.03.004

De Matos, C., \& Rossi, C. (2008). Word of mouth communication in marketing: A meta-analytic review of the antecedents and moderators. Journal of the Academy of Marketing Science, 36(winter), 578-596. https://doi.org/10.1007/s11747-008-0121-1

Dessart, L., Veloutsou, C., \& Morgan-Thomas, A. (2015). Journal of Product and Brand Management, 24(1), 28-42. https://doi.org/10.1108/JPBM-06-2014-0635

Diamatopoulos, A., \& Winklhofer, H. (2001). Index construction with formative indicators: An alternative to scale development. Journal of Marketing Research, 38(2), 269-277. https://doi.org/10.1509/jmkr.38.2.269.18845

Doney, P., \& Cannon, J. (1997). An examination of the nature of trust in buyer-seller relationships. Journal of Marketing, 61(2), 35-51.

Fuller, J. (2010). Refining virtual co-creation from a consumer perspective. California Management Review, 52(2), 98-122. https://doi.org/10.1525/cmr.2010.52.2.98

Fuller, J., Matzler, K., \& Hoppe, M. (2008). Brand community members as a source of innovation. The Journal of Product Innovation Management, 25(6), 608. https://doi.org/10.1111/j.1540-5885.2008.00325.x

Gambetti, R., Graffigna, G., \& Biraghi, S. (2012). The grounded theory approach to Consumer-Brand Engagement. International Journal of Market Research, 54(5), 659-687. https://doi.org/10.2501/IJMR-54-5-659-687

Gebauer, J., Fuller, J., \& Pezzei, R. (2013). The dark and bright side of co-creation: Triggers of member behavior in online innovation communities. Journal of Business Research, 66(9), 1516-1527. https://doi.org/10.1016/j.jbusres.2012.09.013

Gregoire, Y., Tripp, T., \& Legoux, R. (2009). When Customer Love turns into Lasting Hate: The effects of relationship strength and time on customer revenge and avoidance. Journal of Marketing, 73(6), 18-32. https://doi.org/10.1509/jmkg.73.6.18

Gummerus, J., Liljander, V., Weman, E., \& Pihlstrom, M. (2012). Customer engagement in a Facebook brand community. Management Research Review, 35(9), 857-877. https://doi.org/10.1108/01409171211256578

Gustafsson, A., Michael D. J., \& Inger, R. (2005). The Effect of Customer Satisfaction, Relationship Commitment Dimensions, and Triggers on Customer Retention. Journal of Marketing, 69(October), 210-218. https://doi.org/10.1509/jmkg.2005.69.4.210

Ha, H., Janda, S., \& Muthaly, S. K. (2010). A new understanding of satisfaction model in e-re-purchase situation. European Journal of Marketing, 44(7/8), 997-1016. https://doi.org/10.1108/03090561011047490

Hair, J., Hult, G., Ringle, C., \& Sarstedt, M. (2014). A Primer on Partial Least Squares Structural Equation Modeling (PLS-SEM). Sage Publications.

Hair, J., Ringle, C. M., \& Sarstedt, M. (2011). PLS-SEM: Indeed a silver bullet. Journal of Marketing Theory 
and Practice, 19(2), 139-152. https://doi.org/10.2753/MTP1069-6679190202

Hayes, A. (2013). Introduction to mediation, moderation, and conditional process analysis: A regression-based approach. Guilford Publications.

Hair, J., Black, W., Babin, B., \& Anderson, R. (2010). Multivariate data analysis: A global perspective (7th ed.). Upper Saddle River, New Jersey: Pearson Prentice Hall.

Harrison-Walker, L. (2001). The measurement of word-of-mouth communication and an investigation of service quality and customer commitment as potential antecedents. Journal of Service Research, 4(1), 60-75. https://doi.org/10.1177/109467050141006

Henning-Thurau, T., \& Klee, A. (1997). The impact of customer satisfaction and relationship quality on customer retention: A critical reassessment and modle development. Psychology Marketing, 14(8), 737-764. https://doi.org/10.1002/(SICI)1520-6793(199712)14:8<737::AID-MAR2>3.0.CO;2-F

Hollebeek, L. (2011). Demystifying customer engagement: Exploring the loyalty nexus. Journal of Marketing Management, 77(7-8), 785-807. https://doi.org/10.1080/0267257X.2010.500132

Hollebeek, L., \& Chen, T. (2014). Exploring positively_versus negatively—valence brand engagement: a conceptual model. Journal of Product and Brand Management, 23(1), 62-74. https://doi.org/10.1108/JPBM-06-2013-0332

Hoyer, W., Ghandy, R., Dorotic, M., Krafft, M., \& Singh, S. (2010). Consumer co-creation in new product development. Journal of Service Research, 13(3), 283-296. https://doi.org/10.1177/1094670510375604

Jaakkola, E., \& Alexander, M. (2014). The role of customer engagement behavior in value co-creation: A service system perspective. Journal of Service Research, 17(3), 247-261. https://doi.org/10.1177/1094670514529187

Jarvenpaa, S., Tranctinsky, J., \& Vitale, M. (2000). Consumer trust in an internet store. Information Technology Management, 1(1-2), 45-71. https://doi.org/10.1023/A:1019104520776

Keh, H. T., \& Xie, Y. (2009). Corporate reputation and customer behavioral intentions: The roles of trust, identification and commitment. Industrial Marketing Management, 38, 732-742. https://doi.org/10.1016/j.indmarman.2008.02.005

Keiningham, T., Frennea, C., Aksoy, L., Buoye, A., \& Mittal, V. (2015). A five-component customer commitment model: implications for repurchase intentions in goods and services industries. Journal of Service Research, 18(4), 433-450. https://doi.org/10.1177/1094670515578823

Kline, R. (2015). Principles and practice of structural equation modeling. Guilford Press.

Kumar, V., Aksoy, L., Donkers, B., Venkatesan, R., Wiesel, T., \& Sebastian, T. (2010). Undervalued or Overvalued Customers: Capturing Total Customer Engagement Value. Journal of Service Research, 13(3), 297-310. https://doi.org/10.1177/1094670510375602

Lacey, R., \& Morgan, R. (2009). Customer advocacy and the Impact of B2B loyalty programs. Department of Management and Marketing, University of Alabama, Tuscaloo. Journal of Business Industrial Marketing, 24(1), 3-13. https://doi.org/10.1108/08858620910923658

Marketing Science Institute. (MSI). (2010). 2010-2012 research priorities. Retrieved from $\mathrm{http} / / \mathrm{www} . \mathrm{msi}$. org/research/index.cfm?id $1 / 4271$

Martinez, P., \& Rodriguez, D. B. I. (2013). CSR and customer loyalty: The roles of trust, customer identification with the company and satisfaction. International Journal of Hospitality Management, 35, 89-99. https://doi.org/10.1016/j.ijhm.2013.05.009

Mathwick, C., Malhotra, N., \& Rigdon, E. (2001). Experiential Value: Conceptualization, measurement and application in the catalog and internet shopping environment. Journal of Retailing, 77(1), 39-56. https://doi.org/10.1016/S0022-4359(00)00045-2

Meyer, J., \& Allen, N. (1997). Commitment in the workplace: theory, research and application. Thousand oaks, CA: Sage.

Ministry of Higher Education- Egypt. (2017). Retrieved from http://www.mohe-casm.edu.eg

Mittal, V., Rajan S., \& Dholakia, U. (2010). Does Media Coverage of Toyota Recalls Reflect reality? Harvard Business Review Research Blog, 9(March). Retrieved from http://blogs.hbr.org/research/2010/03/does-media-coverage-of-toyota.html 
Mollen, A., \& Wilson, H. (2010). Engagement, telepresence, and interactivity in online consumer experience: Reconciling scholastic and managerial perspectives. Journal of Business Research, 63(9/10), 919-925. https://doi.org/10.1016/j.jbusres.2009.05.014

Mosavi, S., \& Ghaed, M. (2012). A survey on the relationship between trust, customer loyalty, commitment and repurchase intention. African Journal of Business Management, 6(36), 10089-10098. Retrieved from http://www.academicjournals.org/AJBM, https://doi.org/10.5897/AJBM11.2741

Nitzl, C., Roldan, J., \& Cepeda, G. (2016). Mediation analysis in partial least squares path modeling: Helping researchers discuss more sophisticated models. Industrial Management \& Data Systems, 116(9), 1849-1864. https://doi.org/10.1108/IMDS-07-2015-0302

Petruzzellis, L., \& Romanazzi, S. (2010). Educational value: How students choose university. International Journal of Educational Management, 24(2), 139-158. https://doi.org/10.1108/09513541011020954

Preacher, K., \& Hayes, A. (2004). SPSS and SAS procedures for estimating indirect effects in simple mediation models. Behavior Research Methods, Instruments, \& Computers, 36(4), 717-731. https://doi.org/10.3758/BF03206553

Preacher, K., \& Hayes, A. (2008), Asymptotic and re-sampling strategies for assessing and comparing indirect effects in multiple mediator models. Behavior Research Methods, 40(3), 879-891. https://doi.org/10.3758/BRM.40.3.879

Rauyruen, P., \& Miller, K. (2007). Relationship quality as a predictor of B2B customer loyalty. Journal of Business Research, 60(1), 21-31. https://doi.org/10.1016/j.jbusres.2005.11.006

Ringle, C., Wende, S., \& Becker, J.-M. (2015). SmartPLS 3. Boenningstedt: SmartPLS GmbH. Retrieved from http://www.smartpls.com

Rosenbaum, M., \& Massiah, C. (2007). Co-creating unique value with customers. Strategy and Leadership, 32(3), 4-9.

Sekaran, U., \& Boujie, R. (2009). Research Methods for Business: a skill building approach (5th ed.). UK: John Wiley and Sons Ltd. 276.

Sirdesmukh, D., Japtig, S., \& Berry, S. (2002). Customer trust, value and loyalty in relational exchanges. Journal of Marketing, 66, 16-37.

Swean, V., \& Chumpitaz, R. (2008). Impact of corporate social responsibility on consumer trust. Recherché et Applications en Marketing, 23(4), 7-33. https://doi.org/10.1177/205157070802300402

Van Doorn, J., Lemon, K., Mittal, V., Nab, S., Pick, D., Pirner, P., \& Verhoef, P. (2010). Customer engagement behavior: Theoretical foundations and research directions. Journal of Service Research, 13(3), 253-266. https://doi.org/10.1177/1094670510375599

Vargo, S. (2009). Toward a transcending conceptualization of relationship: A service-dominant logic perspective. Journal of Business and Industrial Marketing, 24(5/6), 373-379. https://doi.org/10.1108/08858620910966255

Vargo, S., \& Lusch, R. (2004). Evolving to a new dominant logic for marketing. Journal of Marketing, 68(January), 1-17. https://doi.org/10.1509/jmkg.68.1.1.24036

Vargo, S., \& Lusch, R. (2008). Service-Dominant Logic: continuing the evolution. Journal of the Academy of Marketing Science, 36(1), 1-10. https://doi.org/10.1007/s11747-007-0069-6

Vivek, S., Beatty, S., \& Morgan, R. (2012). Customer engagement: Exploring customer relationships beyond purchase. Journal of Marketing Theory and Practice, 20(2), 127-149. https://doi.org/10.2753/MTP1069-6679200201

Vivek, S., Beatty, S., Vivek D., \& Morgan, R. (2014). A Generalized multidimensional scale of measuring customer engagement. Journal of Marketing Theory and Practice, 22(4), 401-420. https://doi.org/10.2753/MTP1069-6679220404

\section{Copyrights}

Copyright for this article is retained by the author(s), with first publication rights granted to the journal.

This is an open-access article distributed under the terms and conditions of the Creative Commons Attribution license (http://creativecommons.org/licenses/by/4.0/). 